\title{
PENGARUH MODEL PROBLEM BASED LEARNING BERBANTU PETA KONSEP TERHADAP HASIL BELAJAR SISWA SMA
}

\author{
Mardiana Afriany Simatupang, Sehat Simatupang \\ dianasimatupang96@yahoo.com \\ Jurusan Fisika FMIPA Universitas Negeri Medan \\ Jalan Willem Iskandar Pasar V Medan, 20221
}

\begin{abstract}
This study aims to determine the effect of the use of problem-based learning model-assisted learning concept maps on learning outcomes of students in the subject matter of dynamic power in the second half of class X SMA Negeri Medan FY 14 2013/2014. This research is a quasiexperiment with the entire population of students in grade 14 class $\mathrm{X}$ SMA Negeri Medan, amounting to 9 classes. The study sample consisted of two classes defined by cluster random sampling technique, which is a class X IPA-3 by using a model-assisted learning problem based learning concept maps and IPA-2 class X using conventional learning models. The instrument used in this study was twofold: 1) achievement test in the form of multiple choice with 5 possible answers of 20 questions that have been declared valid by the validator. 2) observation sheet student learning activities. The average value of student activities for learning problem-based learning model with the concept of classified activeassisted map. Based on the t test at significance level $\alpha=0.05$ level, we could say that there is an influence model of learning problem-based learning-assisted concept mapping on learning outcomes of students in the subject matter of dynamic electric field in SMA 14 TA 2013/2014.
\end{abstract}

Keywords : problem based learning, concept maps, learning outcomes, activities.

\section{PENDAHULUAN}

Pendidikan pada hakekatnya adalah usaha sadar dan terencana untuk mewujudkan suasana belajar dan proses pembelajaran agar peserta didik secara aktif mengembangkan potensi diri untuk memiliki kekuatan spiritual keagamaan, pengendalian diri, kepribadian, kecerdasan, akhlak mulia, serta keterampilan yang diperlukan dirinya, masyarakat, bangsa dan negara (UU RI No.20 tahun 2003).

Pendidikan merupakan media yang sangat berperan untuk menciptakan manusia yang berkualitas yang berpotensi dalam arti yang seluas-luasnya, melalui pendidikan akan terjadi proses pendewasaan diri sendiri sehingga di dalam proses pengambilan keputusan terhadap suatu masalah yang dihadapi selalu disertai dengan rasa tanggung jawab yang 
besar pendidikan dapat tercapai. Untuk meningkatkan pendidikan tentu saja tidak terlepas dari guru dan proses belajar mengajar sebagai kegiatan utama di sekolah.

Hal ini terbukti dengan hasil wawancara peneliti dengan siswa di sekolah SMA Negeri 14 Medan mengatakan bahwa siswa menginginkan guru mengajar dengan metode yang lebih bervariasi sehingga siswa dapat belajar dengan suasana yang menyenangkan dan mengasyikkan. Siswa juga mengharapkan suasana kelas yang lebih rileks dan tidak kaku. Oleh karena itu, menurut Riyanto (2009:5) bahwa "Guru perlu memiliki pengetahuan tentang pendekatan dan teknik-teknik mengajar yang baik dan tepat sehingga kegiatan belajar yang efektif dan efisien dapat berlangsung sesuai tujuan yang diharapkan".

Permasalahan diatas diperkuat dengan hasil angket yang disebarkan ke 38 siswa kelas X SMA Negeri 14 Medan, diperoleh bahwa $50 \%$ menyatakan bahwa mata pelajaran fisika itu sulit karena hanya menggunakan metode ceramah, $30 \%$ menyatakan bahwa mata pelajaran fisika itu hanya biasa saja, dan 20\% menyatakan bahwa mata pelajaran fisika itu mudah.

Hal ini terjadi karena penggunaan strategi dan metode yang kurang tepat, kurangnya media, sarana dan lain-lain. Di samping itu metode pembelajaran yang digunakan masih konvensional dimana metode mengajarkan dominan ceramah. Alasan menggunakan metode ceramah adalah keterbatasan waktu dan mengejar target kurikulum. Hasil belajar yang dicapai siswa juga tergolong rendah, sekitar 45\% siswa yang dapat memenuhi standar nilai ketuntasan minimum yaitu 75 , sehingga harus dilakukan remedial agar seluruh siswa dapat dinyatakan tuntas terhadap materi yang dipelajari, model pembelajaran yang digunakan masih kurang bervariasi dan kurangnya penggunaan media pembelajaran menjadi penyebab kurang aktifnya siswa dalam proses pembelajaran. Berdasarkan hasil observasi yang dilakukan peneliti mengenai sarana dan prasarana laboratorium di SMA Negeri 14 Medan sudah cukup lengkap tetapi belum digunakan secara maksimal karena keterbatasan waktu. Di sini penulis menawarkan model problem based learning, pembelajaran ini muncul dari konsep bahwa siswa akan lebih mudah menemukan dan memahami konsep yang sulit jika saling berdiskusi dengan temannya dan berusaha mencari akar permasalahan dari lingkungan sekitarnya.

Menurut Arends (2008) model problem based learning merupakan suatu pendekatan pembelajaran dimana siswa mengerjakan permasalahan yang autentik dengan maksud untuk menyusun pengetahuan mereka sendiri, mengembangkan inkuiri dan keterampilan berpikir tingkat lebih tinggi, mengembangkan kemandirian dan percaya diri. Model problem based learning tidak dirancang untuk membantu guru menyampaikan informasi dengan jumlah besar kepada siswa. Di sini 
siswa dituntut mecari informasi lebih luas dari lingkungan sekitarnya. Untuk memperoleh hasil belajar yang lebih baik, model pembelajaran ini disertai dengan media peta konsep guna memudahkan siswa mempelajari dan mengingat hal-hal yang telah dipelajari. Peta konsep dapat digunakan guru untuk menolong siswa mempelajari cara belajar dan mengetahui konsep-konsep yang telah dimiliki siswa agar belajar bermakna dapat berlangsung. Penggunaan model problem based learning mampu meningkatkan hasil

belajar siswa. Penelitian mengena imodel problem based learning ini sudah pernah dilakukan dan dikaji oleh Sitorus (2008) nilai rata-rata pretes siswa sebesar 4,23 atau $42,25 \%$ dan nilai postes 6,97 atau $\quad 69,75 \% \quad$ sudah mencapai nilai ketuntasan.

Berdasarkan uji t diperoleh bahwa model problem based learning secara signifikan lebih baik meningkatkan hasil belajar.

Namun penelitian ini memilik i kelemahan dalam mempersiapkan media dan alat-alat peraga yang digunakan, serta penglokasian waktu yang kurang efisien sehingga kegiatan belajar dan hasil belajar yang diperoleh masih kurang baik. Upaya yang akan dilakukan peneliti untuk mengatasi kelemahan tersebut adalah dengan memberikan model problem based learning disertai peta konsep sebagai salah satu media pembelajaran, sehingga dengan bantuan peta konsep siswa lebih mudah menguasai konsep listrik dinamis. Selain itu, peneliti akan memberikan lembar kerja siswa (LKS) yang relevan dengan kehidupan sehari-hari sehingga siswa lebih mudah mengerjakannya dan membuat rencana pelaksanaan pembelajaran (RPP) dengan pengalokasian waktu seefisien mungkin sehingga diharapkan hasil belajar siswa akan lebih baik.

Adapun yang menjadi tujuan penelitian adalah untuk mengetahui pengaruh model problem based learning berbantu peta konsep pada materi pokok listrik dinamis kelas $\mathrm{X}$ semester II SMA Negeri14 Medan T.A.2013/2014 dan mengetahui aktivitas belajar siswa selama proses pembelajaran dengan menggunakan model problem based learning berbantu peta konsep.

\section{METODE PENELITIAN}

Penelitian ini dilaksanakan di SMA Negeri 14 Medan di Jalan Pelajar Timur Ujung dengan populasi seluruh siswa kelas X SMA Negeri 14 Medan yang terdiri dar isembilan kelas paralel. Teknik pengambilan sampel dilakukan dengan cara tehnik sampel kelas acak (cluster random sampling). Sampel kelas diambil dari populasi sebanyak 2 kelas yaitu kelas X IPA 3 dengan menggunakan model problem based learning dan kelas $\mathrm{X}$ IPA 2 dengan menggunakan pembelajaran konvensional.

Hasil belajar siswa diperoleh dengan memberikan tes pada kedua kelas sebelum dan sesudah diberi perlakuan. Rancangan penelitian quasi experiment ini dengan desain control group pretest-postest design. Rancangan penelitian ini ditunjukkan pada tabel 1 . 
Tabel 1. Desain Penelitian tipe Two Group (Pre test-Post test)

\begin{tabular}{|l|c|c|c|}
\hline \multicolumn{1}{|c|}{ Kelas } & $\begin{array}{c}\text { Pre } \\
\text { test }\end{array}$ & $\begin{array}{c}\text { Perlak } \\
\text { uan }\end{array}$ & $\begin{array}{c}\text { Post } \\
\text { test }\end{array}$ \\
\hline Eksperimen & $\mathrm{T}_{1}$ & $\mathrm{X}$ & $\mathrm{T}_{2}$ \\
\hline Kontrol & $\mathrm{T}_{1}$ & $\mathrm{Y}$ & $\mathrm{T}_{2}$ \\
\hline
\end{tabular}

Keterangan :

$\mathrm{T}_{1}=$ Tes kemampuan awal

$\mathrm{T}_{2}=$ Tes kemampuan akhir

$\mathrm{X}=$ Pembelajaran menggunakan model problem based learning berbantu peta konsep.

$\mathrm{Y}=$ Pembelajaran menggunakan model pembelajaran konvensional.

Alat pengumpul data dalam penelitian ini adalah tes hasil belajar berbentuk pilihan berganda dan observasi. Tes hasil belajar ini digunakan untuk mengetahui kemampuan siswa pada tingkat kognitif dan observasi untuk mengetahui aktivitas belajar siswa. Perincian kisi-kisi tes hasil belajar siswa ditunjukkan pada tabel 2 .

Tabel 2. Perincian kisi-kisi tes hasil belajar siswa

\begin{tabular}{|c|c|c|c|c|c|c|c|}
\hline \multirow{2}{*}{$\begin{array}{c}\text { Materi } \\
\text { Pokok }\end{array}$} & \multicolumn{6}{|c|}{ Kategori } & \multirow{2}{*}{ Jlh } \\
\hline & C1 & $\mathrm{C} 2$ & C3 & $\mathrm{C} 4$ & C5 & C6 & \\
\hline $\begin{array}{l}\text { Kuat } \\
\text { arus, } \\
\text { Tegangan } \\
\text { dan } \\
\text { Hambata } \\
\text { n Listrik. }\end{array}$ & & $\begin{array}{c}2, \\
16\end{array}$ & $\begin{array}{l}6 \\
7\end{array}$ & $\begin{array}{c}17 \\
18\end{array}$ & $\begin{array}{c}20 \\
\dot{14}\end{array}$ & & 7 \\
\hline $\begin{array}{l}\text { Hukum } \\
\text { OHM }\end{array}$ & & & 3 & 13 & & & 2 \\
\hline $\begin{array}{l}\text { Susunan } \\
\text { Hambata } \\
\text { n Listrik }\end{array}$ & & 8 & & 5 & 12 & & 4 \\
\hline $\begin{array}{l}\text { Hukum } \\
\text { Kirchhoff }\end{array}$ & 19 & & 9 & & & 15 & 3 \\
\hline $\begin{array}{l}\text { Alat - } \\
\text { alat ukur } \\
\text { listrik }\end{array}$ & 1 & & 14 & & & & 2 \\
\hline $\begin{array}{l}\text { Biaya } \\
\text { dan daya } \\
\text { lisytrik }\end{array}$ & & & & 10 & & 11 & 2 \\
\hline Jumlah & 2 & 3 & 5 & 5 & 3 & 2 & 20 \\
\hline
\end{tabular}

Uji hipotesis dilaksanakan dengan membandingkan rata-rata skor hasil belajar yang dicapai baik kelompok eksperimen maupun kelompok kontrol. Data yang diperoleh ditabulasikan kemudian dicari rata-ratanya. Sebelum dilakukan penganalisian data, terlebih dahulu ditentukan skor masing-masing kelompok sampel lalu dilakukan pengolahan data dengan langkah-langkah sebagai berikut:

a) Menghitung nilai rata-rata dan simpangan baku

b) Uji Normalitas dan Uji Homogenitas. Uji normalitas dan uji homogenitas dimaksudkan sebagai prasyarat melakukan uji hipotesis jika data terdistribusi normal dan homogen.

c) Pengujian Hipotesis (uji t)

Uji $\mathrm{t}$ dua pihak digunakan untuk mengetahui kesamaan kemampuan awal siswa pada kedua kelompok sampel. Hipotesis yang diuji berbentuk :

Ho $: \mu_{1}=\mu_{2}:$ kelas eksperimen dan kelas kontrol mempunyai kemampuan awal yang sama.

$\mathrm{Ha}: \mu_{1} \neq \mu_{2}:$ kelas eksperimen dan kelas kontrol mempunyai kemampuan awal yang berbeda.

Data penelitian yang terdistribusi normal dan homogen dilanjutkan dengan menguji hipotesis menggunakan uji beda dengan rumus (Sudjana, $2005: 239$ )

$$
t_{\text {hitung }}=\frac{\overline{X_{1}}-\overline{X_{2}}}{S \sqrt{\left(\frac{1}{n_{2}}\right)+\left(\frac{1}{n_{2}}\right)}}
$$


Analisis data yang menunjukkan $-t_{1}-\frac{1}{2} \alpha<t<t_{1}-\frac{1}{2} \alpha$

maka hipotesis $\mathrm{H}_{0}$ diterima, berarti kemampuan awal siswa pada kelas kontrol sama dengan kemmapuan awal siswa pada kelas eksperimen. Dan jika analisis data menunjukkan harga $t$ yang lain, maka $\mathrm{H}_{\mathrm{o}}$ ditolak diterima $\mathrm{Ha}$, berarti kemampuan awal siswa pada kelas eksperimen tidak sama dengan kemampuan awal siswa pada kelas kontrol.

Uji $t$ digunakan untuk mengetahui pengaruh dari suatu perlakuan yaitu dalam penelitian model problem based learning berbantu peta konsep terhadap hasil belajar siswa. Hipotesis yang diuji berbentuk:

$$
\begin{aligned}
& \text { Ho }: \mu_{1}=\mu_{2} \\
& \text { Ha }: \mu_{1}>\mu_{2}
\end{aligned}
$$

Keterangan :

$\mu_{1}=\mu_{2}$ : Tidak ada perbedaan hasil belajar siswa akibat pengaruh model pembelajaran problem based learning berbantu peta konsep dengan pembelajaran konvensional pada materi pokok listrik dinamis kelas $\mathrm{X}$ semester II SMA Negeri 14 Medan T.A.2013/2014.

$\mu_{1}>\mu_{2}$ : Ada perbedaan hasil belajar siswa akibat pengaruh model pembelajaran problem based learning berbantu peta konsep dengan pembelajaran konvensional pada materi pokok listrik dinamis kelas $\mathrm{X}$ semester II SMA Negeri 14 Medan T.A.2013/2014.

Data penelitian yang terdistribusi normal dan homogen dilanjutkan dengan menguji hipotesis menggunakan uji t dengan rumus, yaitu :

$$
t=\frac{\overline{X_{1}}-\overline{X_{2}}}{S \sqrt{\frac{1}{n_{1}}+\frac{1}{n_{2}}}}
$$

Berdasarkan analisis data menunjukkan bahwa, $t<t_{1-\alpha}$ atau nilai t hitung yang diperoleh lebih dari $t_{1-\alpha}$, maka hipotesis Ho ditolak dan $\mathrm{Ha}$ diterima. Dapat diambil kesimpulan hasil belajar siswa pada kelas eksperimen lebih besar daripada hasil belajar siswa kelas kontrol, maka model problem based learning berbantu peta konsep berpengaruh terhadap hasil belajar siswa.

\section{HASIL DAN PEMBAHASAN}

Adapun hasil penelitian ini adalah bahwa nilai rata-rata pretes kelas eksperimen sebesar sebesar 3,190 dan nilai rata-rata kelas kontrol sebesar 4,575. Setelah diberikan perlakuan yang berbeda dimana pada kelas eksperimen diberikan pembelajaran dengan model problem based learning berbantu peta konsep dan pada kelas kontrol diberikan pembelajaran konvensional, diperoleh bahwa rata-rata postes kelas eksperimen sebesar 6,138 dan rata-rata postes kelas kontrol sebesar 5,488. Hasil ini berarti hasil belajar siswa pada kelas kontrol mengalami peningkatan sebesar 0,913 dan pada kelas eksperimen sebesar 2,948. Dari hasil ini tampak bahwa nilai postes kelas eksperimen lebih tinggi dibandingkan dengan kelas kontrol. Sehingga dapat dikatakan bahwa model problem based learning berbantu peta konsep memberikan pengaruh yang signifikan terhadap hasil belajar siswa pada materi pokok listrik 
dinamis kelas X semester II SMA Negeri 14 Medan.

Data nilai pretes kelas kontrol dan kelas eksperimen ditunjukkan pada gambar 1 .

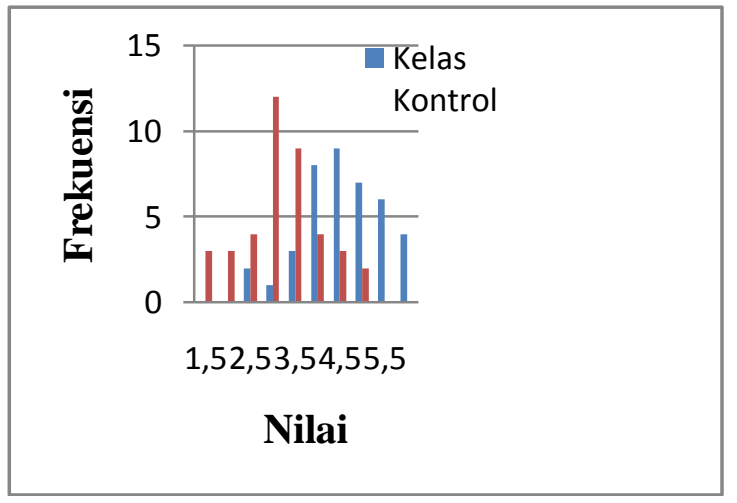

Gambar 1. Diagram batang data nilai pretes kelas kontrol dan kelas eksperimen

Data nilai postes kelas eksperimen dan kelas kontrol ditunjukkan pada gambar 2 .

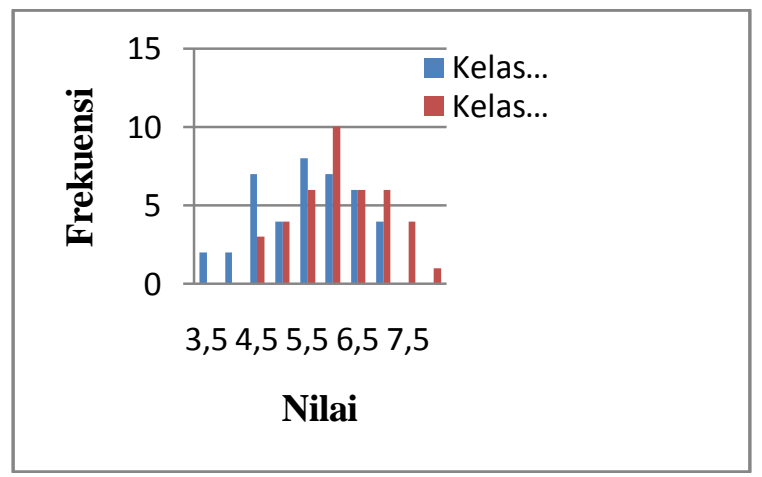

Gambar 2. Diagram batang data pos tes kelas eksperimen dan kelas kontrol

Uji normalitas data pretes dan postes kelas eksperimen dan kelas kontrol menggunakan uji lilliefors, setelah dilakukan pengujian maka data pretes dan postes kedua kelas terdistribusi normal. Uji homogenitas pretes dan postes kelas kontrol menggunakan uji kesamaan dua varians.
Berdasarkan hasil pengujian ini data kedua kelompok sampel dinyatakan homogen sehingga layak dilakukan uji hipotesis dengan hasil ringkasan perhitungan uji hipotesis kemampuan pretes ditunjukkan pada tabel 3 .

Tabel 3. Ringkasan perhitungan uji hipotesis kemampuan pretes

\begin{tabular}{|c|c|c|c|c|}
\hline Data & $\begin{array}{l}\text { Rata } \\
\text {-rata }\end{array}$ & thitung & $t_{\text {tabel }}$ & $\begin{array}{c}\text { Kesimp } \\
\text { ulan }\end{array}$ \\
\hline $\begin{array}{l}\text { Pretes } \\
\text { Kelas } \\
\text { eksperim } \\
\text { en }\end{array}$ & 3,19 & \multirow[t]{2}{*}{$-0,69$} & \multirow[t]{2}{*}{1,99} & \multirow{2}{*}{$\begin{array}{c}\text { Kemam } \\
\text { puan } \\
\text { awal } \\
\text { siswa } \\
\text { sama }\end{array}$} \\
\hline $\begin{array}{l}\text { Pretes } \\
\text { Kelas } \\
\text { kontrol }\end{array}$ & 4,57 & & & \\
\hline
\end{tabular}

Ringkasan perhitungan uji hipotesis kemampuan postes siswa ditunjukkan pada tabel 4 .

Tabel 4. Ringkasan Perhitungan uji hipotesis kemampuan postes

\begin{tabular}{|c|c|c|c|c|}
\hline Data & $\begin{array}{l}\text { Rata } \\
\text {-rata }\end{array}$ & thitung & ttabel & $\begin{array}{c}\text { Kesimp } \\
\text { ulan }\end{array}$ \\
\hline $\begin{array}{l}\text { Postes } \\
\text { Kelas } \\
\text { Eksperi } \\
\text { men }\end{array}$ & $\begin{array}{c}6,13 \\
8\end{array}$ & \multirow[t]{2}{*}{3,09} & \multirow[t]{2}{*}{1,99} & \multirow{2}{*}{$\begin{array}{c}\text { Ada } \\
\text { perbeda } \\
\text { an yang } \\
\text { signifik } \\
\text { an }\end{array}$} \\
\hline $\begin{array}{l}\text { Postes } \\
\text { Kelas } \\
\text { Kontrol }\end{array}$ & $\begin{array}{c}5,48 \\
8\end{array}$ & & & \\
\hline
\end{tabular}

Observasi dilakukan selama kegiatan belajar mengajar yang dilakukan selama tiga kali pertemuan baik di kelas eksperimen maupun kelas kontrol. Hasil observasi para observer ditunjukkan pada gambar 3 . 


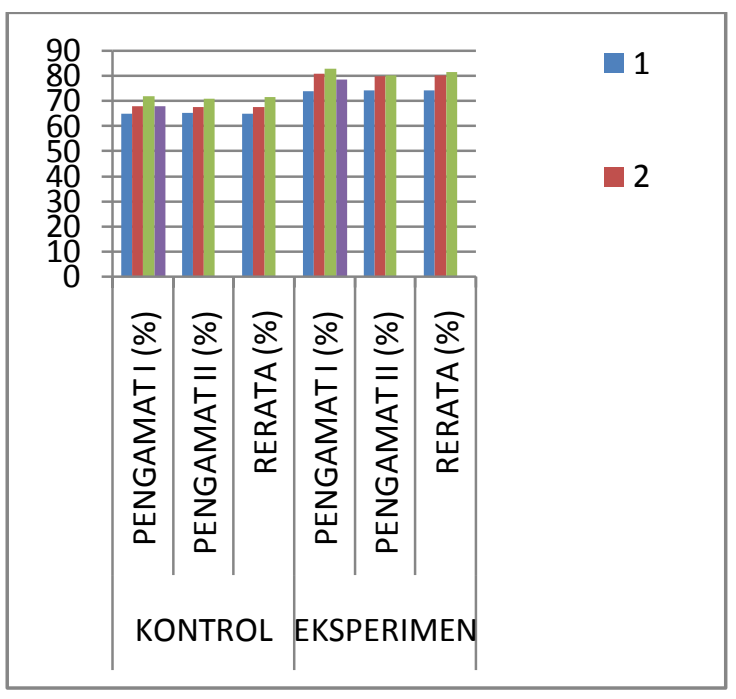

Gambar 3. Diagram batang perkemb angan aktivitas siswa kelas eksperimen dan kelas kontrol

Hasil penelitian menunjukkan bahwa ada pengaruh model problem based learning berbantu peta konsep terhadap hasil belajar fisika siswa pada materi pokok Listrik Dinamis kelas $\mathrm{X}$ semester II SMA Negeri 14 Medan. Hal ini ditunjukkan dengan adanya perbedaan peningkatan hasil belajar kelas eksperimen dengan kelas kontrol yaitu kelas eksperimen dengan nilai rata-rata postes 6,138 sedangkan pada kelas kontrol dengan nilai rata-rata 5,488. Demikian juga aktivitas siswa pada kelas eksperimen mengalami peningkatan yaitu pada pertemuan I rata-rata aktivitas siswa kelas eksperimen 73,985 , pada pertemuan II rata-rata adalah 80,160 sedangkan pada pertemuan III meningkat menjadi 81,410. Jadi dari keseluruhan diperoleh nilai ratarata aktivitas siswa selama pembelajaran dengan model problem based learning berbantu peta konsep adalah 78,52 dan digolongkan aktif. Pada kelas kontrol aktivitas siswa juga mengalami peningkatan yaitu pada pertemuan I rata-rata 64,925 , pada pertemuan II rata-rata adalah 67,575 sedangkan pada pertemuan III meningkat menjadi 71,410. Jadi nilai rata-rata aktivitas siswa selama pembelajaran dengan model pembelajaran konvensional adalah 67,97 dan digolongkan cukup aktif.

Berdasarkan gambar 3 diagram batang perkembangan aktivitas siswa kelas eksperimen dan kelas kontrol terlihat bahwa nilai rata-rata aktivitas siswa sebanding dengan kenaikan nilai postes siswa, namun 2 orang siswa yang nilai aktivitasnya cukup aktif tetapi nilai postesnya kurang, hal ini berarti kemampuan kognitif siswa itu rendah. Selain itu 10 orang pada kategori kurang untuk pretes sedangkan aktivitasnya sedang dan postesnya baik, disisi lain ada 2 orang siswa yang pretes kurang, aktivitas sangat aktif dan postesnya baik, ini berarti hasil belajar siswa dibanding aktivitasnya sangat aktif dan postesnya baik, ini berarti siswa dibanding aktivitasnya menurut penelitian ini beragam. Hal ini disebabkan karena pengaruh faktor dari luar yaitu banyak siswa yang ikut tes belajar diluar sekolah sehingga hasil postesnya baik. Hasil penelitian ini sesuai dengan penelitian terdahulu yaitu Sitorus (2008) mengatakan bahwa model ini cocok digunakan untuk mengukur kemampuan berpikir kritis siswa.

Hasil belajar fisika siswa dalam penelitian karena adanya beberapa kebaikan dari model pembelajaran problem based learning berbantu peta konsep dibandingkan dengan pembelajaran 
konvensional, dimana model pembelajaran problem based learning lebih berpusat pada siswa sehingga siswa lebih aktif untuk mengkonstruksi langsung pengetahuan melalui setiap kegiatan yang telah dirancang pada fase problem based learning. Pada kelas kontrol pembelajaran berpusat pada guru, sedangkan siswa hanya mendengar saja, tidak terlalu banyak melibatkan siswa dalam bekerja. Selain itu, model problem based learning ini mempunyai keunggulan dibandingkan dengan pembelajaran konvensional antara lain : semua anggota kelompok wajib mendapat tugas. Hal ini menyebabkan setiap anggota kelompok aktif, ada interaksi antara siswa dengan siswa dan siswa dengan guru, siswa terlatih untuk mengembangkan keterampilan komunikasi sosial, mendorong siswa menghargai pendapat orang lain, dan meningkatkan kemampuan akademik siswa serta melatih siswa untuk berbicara di depan kelas.

Lebih lanjut, pelaksanaan pembelajaran ini terfokus pada lima komponen utama model problem based learning, yaitu : 1) Orientasi siswa pada masalah; penyampaian materi ajar dilengkapi dengan bantuan peta konsep tentang materi listrik dinamis guna meningkatkan daya ingat siswa terhadap materi yang diajarkan, 2) Mengorganisasikan siswa untuk belajar; setiap siswa diajak untuk mengelompokkan diri ke teman lainnya untuk dapat menyelesaikan masalah bersama, 3) Membantu menyelidiki secara mandiri atau kelompok; siswa berusaha untuk mencari penyelesaian masalah, 4)
Mengembangkan dan menyajikan hasil kerja; setiap kelompok yang sudah mampu memecahkan masalah harus dipresentasikan untuk melatih siswa berbicara di depan kelas, 5) Menganalisa dan mengevaluasi hasil pemecahan; siswa mampu menganalisa setiap penjelasan masalah yang dikemukan oleh teman kelompoknya.

Pelaksanaan

kelima komponen inilah yang menyebabkan siswa lebih aktif terutama belajar dalam tim kelompok yang diberikan perorangan yang dijadikan sebagai dasar pemberian nilai kelompok, dalam hal ini masing-masing siswa berusaha bertanggungjawab secara individu untuk melakukan yang terbaik sebagai kesuksesan kelompoknya, sehingga hasil belajar siswa lebih tinggi dibandingkan kelasa kontrol.

Namun demikian, dalam pelaksanaan model pembelajaran ini masih mengalami kelemahan dan kendala yang dihadapi peneliti. Kendala tersebut antara lain: 1) Pembagian kelompok siswa dalam kelompok belajar membutuhkan waktu yang lama ditambah dengan adanya siswa yang tidak memiliki hubungan yang baik dengan teman kelompoknya, sehingga peneliti harus berusaha mendamaikan anggota kelompok yang tidak harmonis terlebih dahulu. 2) Pada saat praktikum berlangsung peneliti masih kesulitan dalam membimbing penuh pada masing-masing kelompok. 


\section{KESIMPULAN DAN SARAN}

Kesimpulan

Kesimpulan penelitian ini didasarkan pada temuan-temuan dari data-data hasil penlitian, sistematika sajiannya dilakukan dengan memperhatikan tujuan penelitian yang telah dirumuskan. Dari hasil penelitian ini tampak bahwa nilai postes kelas eksperimen lebih tinggi dibandingkan dengan kelas kontrol sehingga dapat dikatakan bahwa model problem based learning memberikan pengaruh yang signifikan terhadap hasil belajar siswa pada materi pokok listrik dinamis kelas X semester II SMA Negeri 14 Medan. Dari hasil observasi didapatkan bahwa penerapan model problem based learning berbantu peta konsep dapat meningkatkan aktivitas belajar siswa terkait materi listrik dinamis yaitu dengan kategori aktif.

\section{Saran}

Berdasarkan

kendala tersebut disarankan kepada peneliti selanjutnya diharapkan lebih mengarahkan siswa dalam bekerja dan lebih memahami langkahlangkah model pembelajaran problem based learning. Apabila langkah-langkah model pembelajaran problem based learning berbantu peta konsep dapat dilakuan dengan seefektif mungkin dan penggunaan alokasi waktu yang seefisien mungkin serta kendala-kendala yang ditemukan dapat diminimalisir maka model pembelajaran problem based learning berbantu peta konsep dapat dijadikan salah satu model pembelajaran yang diharapkan dapat memperbaiki hasil belajar siswa fisika untuk masa yang akan datang.

\section{DAFTAR PUSTAKA}

Arends, R., (2008), Learning To Teach Penerbit Pustaka Pelajar, Yogyakarta.

Depkemdikbud, (2006), UU Sistem Pendidikan Nasional, Penerbit Pustaka Pelajar, Yogyakarta

Riyanto, Y., (2009), Paradigma Baru Pembelajaran. Surabaya

Penerbit Kencana Prenada Media Group, Jakarta

Sitorus, (2008). Pengaruh Model Pembelajaran Berbasis Masalah Terhadap Kemampuan Berpikir Kritis Siswa Pada Materi Pokok Usaha dan Energi Kelas XI SMA N 1 DolokSanggul T.P 2011/2012

Sudjana, (2002), Metoda Statistika.

Penerbit Tarsito, Bandung. 